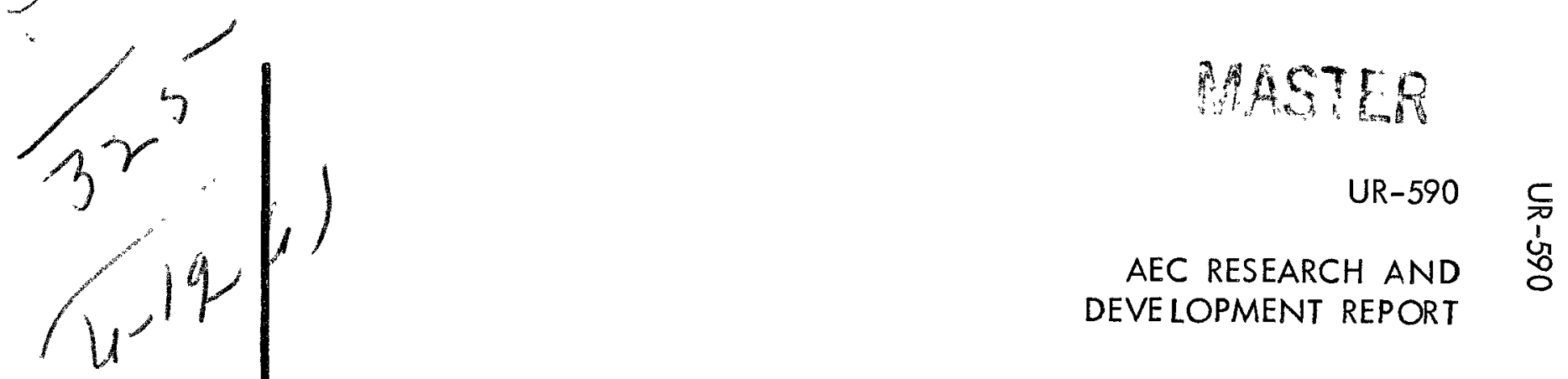

THE INHALATION TOXICITY OF INDIUM SESQUIOXIDE IN THE RAT by
L。 Jo Leach
J。K. Scott
R. D。 Armstrong
L. T. Steadman
E. A. Maynard

\title{
THE UNIVERSITY OF ROCHESTER
}

\section{ATOMIC ENERGY PROJECT ROCHESTER, NEW YORK}


This report was prepared as an account of Government sponsored work. Neither the United States, nor the Commission, nor any person acting on behalf of the Commission:

A. Makes any warranty or representation, expressed or implied, with respect to the accuracy, completeness, or usefulness of the information contained in this report, or that the use of any information, apparatus, method, or process disclosed in this report may not infringe privately owned rights; or

B. Assumes any liabilities with respect to the use of, or for damages resulting from the use of any information, apparatus, method, or process disclosed in this report.

As used in the above, "person acting on behalf of the Commission" includes any employee or contractor of the Commission, or employee of such contractor, to the extent that such employee or contractor of the Commission, or employee of such contractor prepares, disseminates, or provides access to, any information pursuant to his employment or contract with the Commission, or his employment with such contractor. 
Biology and Medicine TID-4500, (15th Ed.)

\author{
THES UNIVERSITY OF ROCHESTER \\ Atomic Inergy Project \\ P. O. Box 287, station 3 \\ Rochester 20 , New York \\ $* * *$
}

Contract $-7401-e n g-49$ between the U. S. Atomic Energy Commission and the University of Rochester, administered by the Department of Radiation Biology of the School of Medicine and Dentistry.

THE INHALATION TOXICITY OF INDIUM SESQUIOXIDE IN THE RAT

\author{
by \\ I. J. Leach \\ 3. K. Seott \\ R. D. Armstrong \\ I. T. Steadman \\ E. A. Maynard
}

From the Division of Radiation Chemistry and Toxicology

Date Completed: $2 / 10 / 61$

Date of Issue: $5 / 10 / 61$

$U N C I A D S I F I E D$ 
• 


\section{DISCLAIMER}

This report was prepared as an account of work sponsored by an agency of the United States Government. Neither the United States Government nor any agency Thereof, nor any of their employees, makes any warranty, express or implied, or assumes any legal liability or responsibility for the accuracy, completeness, or usefulness of any information, apparatus, product, or process disclosed, or represents that its use would not infringe privately owned rights. Reference herein to any specific commercial product, process, or service by trade name, trademark, manufacturer, or otherwise does not necessarily constitute or imply its endorsement, recommendation, or favoring by the United States Government or any agency thereof. The views and opinions of authors expressed herein do not necessarily state or reflect those of the United States Government or any agency thereof. 


\section{DISCLAIMER}

Portions of this document may be illegible in electronic image products. Images are produced from the best available original document. 
TABLE OF CONTENTS

LIST OF TABLES.............................. 4

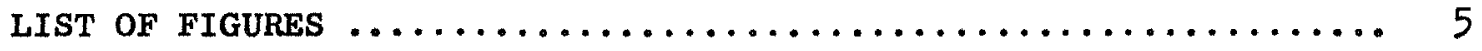

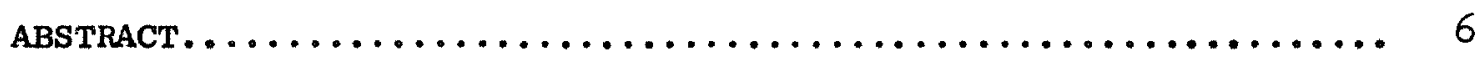

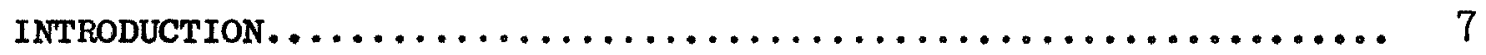

MATERIALS AND METHODS........................ 7

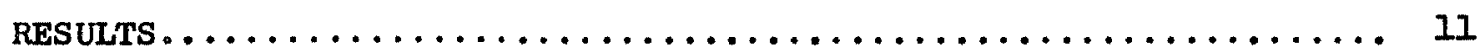

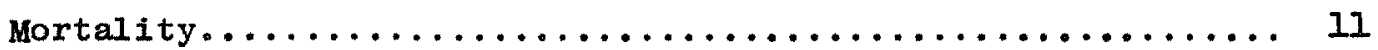

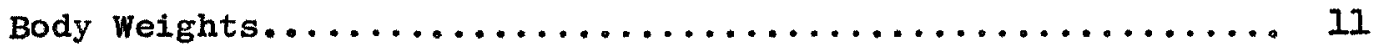

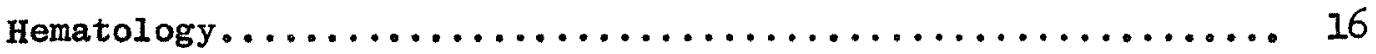

Lung Weights and Lung Weight-Body Weight Ratios......... 16

Indium Content of Tissues..................... 20

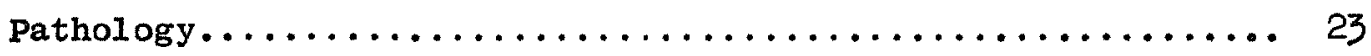

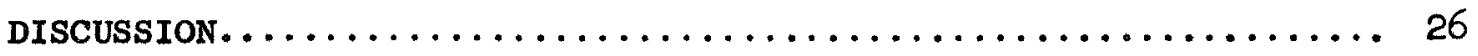

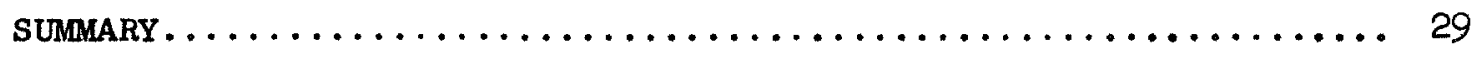

REFERENCES..................................... 30 


\section{LIST OF TABLES}

TABLE I Summary of Conditions of Exposure of Rats to

$\mathrm{In}_{2} \mathrm{O}_{3}$ Dust.............................. 8

TABLE II Body Weight Record - Male Rats.............. 12

TABLE III Body Weight Record - Female Rats............. 13

TABLE IV Average Hematological values................ 17

TABLE $\mathrm{V}$ Lung Weights and Lung Weight-Body Weight Ratios -

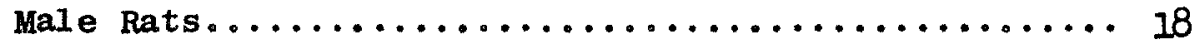

TABLE VI Lung Weights and Lung Weight-Body Weight Ratios -

Female Rats........................... 19

TABLE VII Indium Content of Tissues of Rats Exposed to

$\mathrm{In}_{2} \mathrm{O}_{3}$ Dust............................... 2 I 


\section{LIST OF FIGURES}

FIGURE 1. Chamber Dust Concentration Vs. Exposure Time......... 9

FIGURE 2. Body Weight Curves - Male Rats................... 14

FIGURE 3. Body Weight Curves - Female Rats.............. 15

FIGURE 4. Indium Content of Rat Tissues Vs. Time........... 22

FIGURE 5. Lung ( $H$ and E Mag. $x$ 150) 12 Weeks Post-Exposure..... 24

FIGURE 6. Lung ( $\mathrm{H}$ and $\mathrm{E}$ Mag. $\mathrm{x}$ 300) 2 Weeks Exposure........ 24

FIGURE 7. Lung ( $\mathrm{H}$ and $\mathbf{E}$ Mag. $\mathbf{x}$ 300) 7 Weeks Exposure......... 25

FIGURE 8. Lung ( $\mathrm{H}$ and $\mathrm{E}$ Mag. $\mathrm{x}$ 150) 7 Weeks Exposure........ 25

FIGURE 9. Tracheobronchial Lymph Node (H and E Mag. $x$ 300)

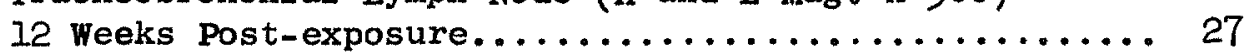




\section{THE INHALATION TOXICITY OF INDIUM SESQUIOXIDE IN THE RAT}

\section{ABSTRACT}

Fifty-four albino rats were exposed to a submicronic aerosol of

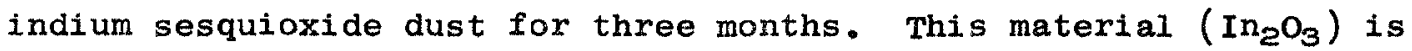
moderately toxic when inhaled at relatively high concentrations $\left(64 \mathrm{mg} / \mathrm{m}^{3}\right)$. Evidence of chemical toxicity was found in body weight changes, in the hematological picture and in the gross and histological condition of the lungs and tracheobronchial $1 \mathrm{ymph}$ nodes.

The retention of indium in the tissues was followed in serially sacrificed animals. An appreciable accumulation occurred in the lungs and tracheobronchial 1 ymph nodes. Average values for these tissues increased from 490 and $250 \mu \mathrm{g} / \mathrm{g}$ fresh tissue, respectively, after two weeks of exposure, to 1000 and $1300 \mu \mathrm{g} / \mathrm{g}$ after 12 weeks. Postexposure data indicate that approximately 58 per cent of the indium had been mobilized from the lungs and 69 per cent from the tracheobronchial Iymph nodes, 12 weeks after termination of exposure.

For other tissues, i.e., liver, kidney and spleen, the indium content was Iow. After two weeks of exposure, average values were as follows: liver, $0.33 \mu \mathrm{g} / \mathrm{g}$; kidney, $1.8 \mu \mathrm{g} / \mathrm{g}$; and spleen, $0.25 \mu \mathrm{g} / \mathrm{g}$. Later in the experiment, viz., 12 weeks post-exposure, the content increased 40-fold in the liver, 6-fold in the kidney, and 80-fold in the spleen. In the interval from the fourth week of exposure to the end of the post-exposure period, there was a 20 -fold increase in the indium content of bone. 
THE INHALATION TOXICITY OF INDIUM SESQUIOXIDE IN THE RAT

\section{INTRODUCTION}

The increased use of indium has necessitated further investigation of the toxicity and of the biological fate of this element and some of its compounds. To supplement information al ready obtained at this 1 aboratory $(1,2,3,4)$, an experiment was conducted to determine the toxicity of indium sesquioxide $\left(\mathrm{In}_{2} \mathrm{O}_{3}\right)$ when inhaled by the rat.

\section{MATERIALS AND METHODS}

Indium sesquioxide $\left(\mathrm{In}_{2} \mathrm{O}_{3}\right)$ in the form of a finely divided yellow dust was obtained from a commercial source*. The test material was used as it was received; no attempt was made to alter particle size. The $\mathrm{In}_{2} \mathrm{O}_{3}$ dust was dispersed from a Wright Dust Feed Mechanism (5) into the inlet air system of an exposure chamber having an internal capacity of approximately one cubic meter. The exposure apparatus will be described in detail elsewhere.

Animal exposure conditions are summarized in Table I. The atmospheric concentration of $\mathrm{In}_{2} \mathrm{O}_{3}$ dust averaged $64 \mathrm{mg} / \mathrm{m}^{3}$ as determined by gravimetric analysis of filter paper** dust samples taken each hour during exposure. Individual hourly dust concentrations are plotted graphically in Figure 1. During the 224 hours of exposure the concentration ranged from 24 to $97 \mathrm{mg} \mathrm{In}_{2} \mathrm{O}_{3} / \mathrm{m}^{3}$.

* The Indium Corporation of America, Utica, New York.

** Milipore filter paper obtained from Millipore Filter Corporation, Watertown 72, Massachusetts was used. 
TABLE I

SUMMARY OF CONDITIONS OF EXPOSURE OF RATS TO $\mathrm{In}_{2} \mathrm{O}_{3}$ DUST

Duration, Calendar Months- . . . . . . - 3

Exposure Schedule

Hours/Day- _ . . . . . . . - . 4

Days/Week- - - - - . - - - - 5

Dust Concentration, mg $\mathrm{In}_{2} \mathrm{O}_{3} / \mathrm{m}^{3}$

Average- . . . . . . . . . . 64

Range- . . . . . . . . . . . - 24- 97

\section{Particle size}

Average CMD, Microns- - . . . . . 0.182

Average og - . . . . . . . . - 2.06

Average Calculated MMD - . - . - . - 0.63

Average of $\ldots-\ldots . . \ldots 1 .+\ldots 1$

Temperature, Degrees Fahrenheit

Daily Average- - . - . . . . - . 74

Range- _. . . . . . . . . - 65 - 80

Relative Humidity, Per cent

Daily Average - _ . $\ldots \ldots 60$

Range- - . . . . . . . . . - $40-84$ 


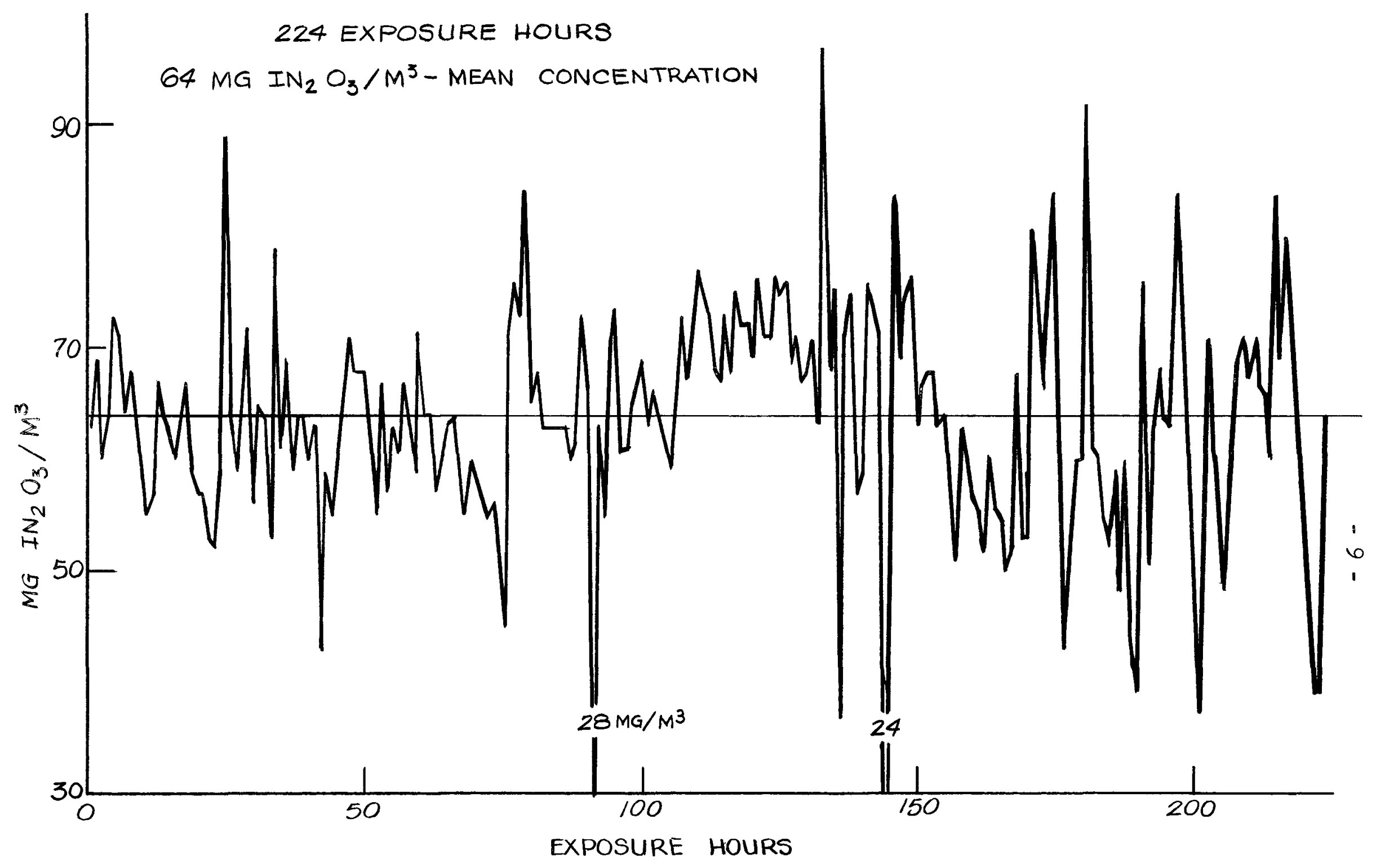

FIGURE 1. Chamber Dust Concentration vs. Exposure Time. 
The relation between the dust load on the filter papers and the quantity of $\mathrm{In}_{2} \mathrm{O}_{3}$ present was checked by analyzing spectrographically one sample daily for indium. The average recovery of indium calculated as $\mathrm{In}_{2} \mathrm{O}_{3}$, corresponded to 96 per cent of the dust load determined gravimetrically.

The particle size distribution of the dust in the test chamber was determined in samples taken with a thermal precipitator, shadowed with chromium at $45^{\circ}$ and photographed in an electron microscope. Characteristics of the aerosol are shown in Table I.

During the course of the experiment the temperature of the air within the chamber varied between 65 and $80^{\circ} \mathrm{Fo}$, the relative humidity between 40 and 84 per cent. As shown in Table I, the average temperature was $74^{\circ} \mathrm{F}$. and the average relative humidity, 60 per cent.

A total of 54 albino rats (27 males and 27 females) was exposed to the $\mathrm{In}_{2} \mathrm{O}_{3}$ dust. All were young adults from the Wistar-derived (1923) Project Colony. Twenty rats of each sex and of the same age were maintained as controls. Preceding the exposure, the animals were conditioned in the chamber for approximately one month. During this time they were subjected to conditions similar to those during exposure, except that $\mathrm{In}_{2} \mathrm{O}_{3}$ dust was not present, and data were obtained that provided control values for hematology. During the dust exposure, body weight, mortality, and clinical appearance of the animals were recorded. Pairs of rats of each sex were sacrificed by ether inhalation at exposure weeks $2,4,7$, and 12 (termination of exposure). Similar groups of control rats were handled in the same manner. Prior to sacrifice, 
blood samples were taken from each experimental animal for hematological study. At 12 weeks post-exposure the remaining animals comprising six exposed rats and four control animals were sacrificed.

At sacrifice, the rats were examined grossly and the lungs were weighed. Sections of the lungs, tracheobronchial lymph nodes (PLN), liver, kidney, spleen, and femur were fixed in Bouin's solution for histopathological study. Portions of these tissues were reserved for spectrographic determination of the indium content.

\section{RESULTS}

\section{Mortality.}

A total of 13 experimental rats comprising seven males and six females died during the 3-month exposure to $\mathrm{In}_{2} \mathrm{O}_{3}$. One rat of each sex died in the control group. The significance of the higher mortality in the indium-exposed animals is difficult to assess because various intercurrent infections, principally acute purulent pleurisy and pericarditis, were the usual causes of death.

Body Weights.

The body weight data for males and females are tabulated in Tables II and III, respectively。 Average body weights are plotted graphically in Figures 2 and 3. A marked growth depression observed in the experimental male rats is evident, Figure 2. This depression became evident between the first and second months of exposure and persisted throughout the post-exposure period. It reached a maximum during the 
TABLE II

BODY WEIGHT RECORD - MALE RATS

\begin{tabular}{|c|c|c|c|c|c|c|}
\hline & & XPERIMEN' & CALS & & CONTROLS & \\
\hline Calendar & No. & Body & Wt., gms. & No. & Body & $\circ$ gms. \\
\hline Time & Rats & Average & Range & Rats & Average & Range \\
\hline 3 wks. pre-exp. & 26 & 190 & $158-248$ & - & - & - \\
\hline 12 days pre-exp. & 26 & 175 & $133-231$ & 20 & 230 & $178-280$ \\
\hline 1 wk。 pre-exp. & 26 & 200 & $134-265$ & 19 & 235 & $183-280$ \\
\hline 1 exp. day & 26 & 230 & $191-293$ & 19 & 245 & $194-285$ \\
\hline 1 exp. wk. & 26 & 250 & $207-328$ & 19 & 265 & $214-303$ \\
\hline 3 exp. wks. & 22 & 265 & $213-337$ & 16 & 275 & $219-321$ \\
\hline 5 exp. wks. & 16 & 270 & $216-360$ & 14 & 285 & $232-339$ \\
\hline 7 exp. wks. & 14 & 280 & $232-350$ & 14 & 295 & $251-359$ \\
\hline 9 exp. wks. & 8 & 265 & $242-326$ & 12 & 305 & $268-360$ \\
\hline 11 exp。wks。 & 7 & 265 & $240-334$ & 12 & 320 & $283-380$ \\
\hline I wk. post-exp. & 3 & 250 & $237-261$ & 10 & 340 & $292-403$ \\
\hline 4 wks. post-exp. & 3 & 254 & $231-268$ & 10 & 345 & $294-415$ \\
\hline 7 wks。post-exp。 & 2 & 272 & $264-279$ & 10 & 355 & $301-427$ \\
\hline 12 wks, post-exp. & 2 & 284 & $284-284$ & 2 & 362 & $316-408$ \\
\hline
\end{tabular}




\section{TABLE III}

BODY WEIGHT RECORD - FEMALE RATS

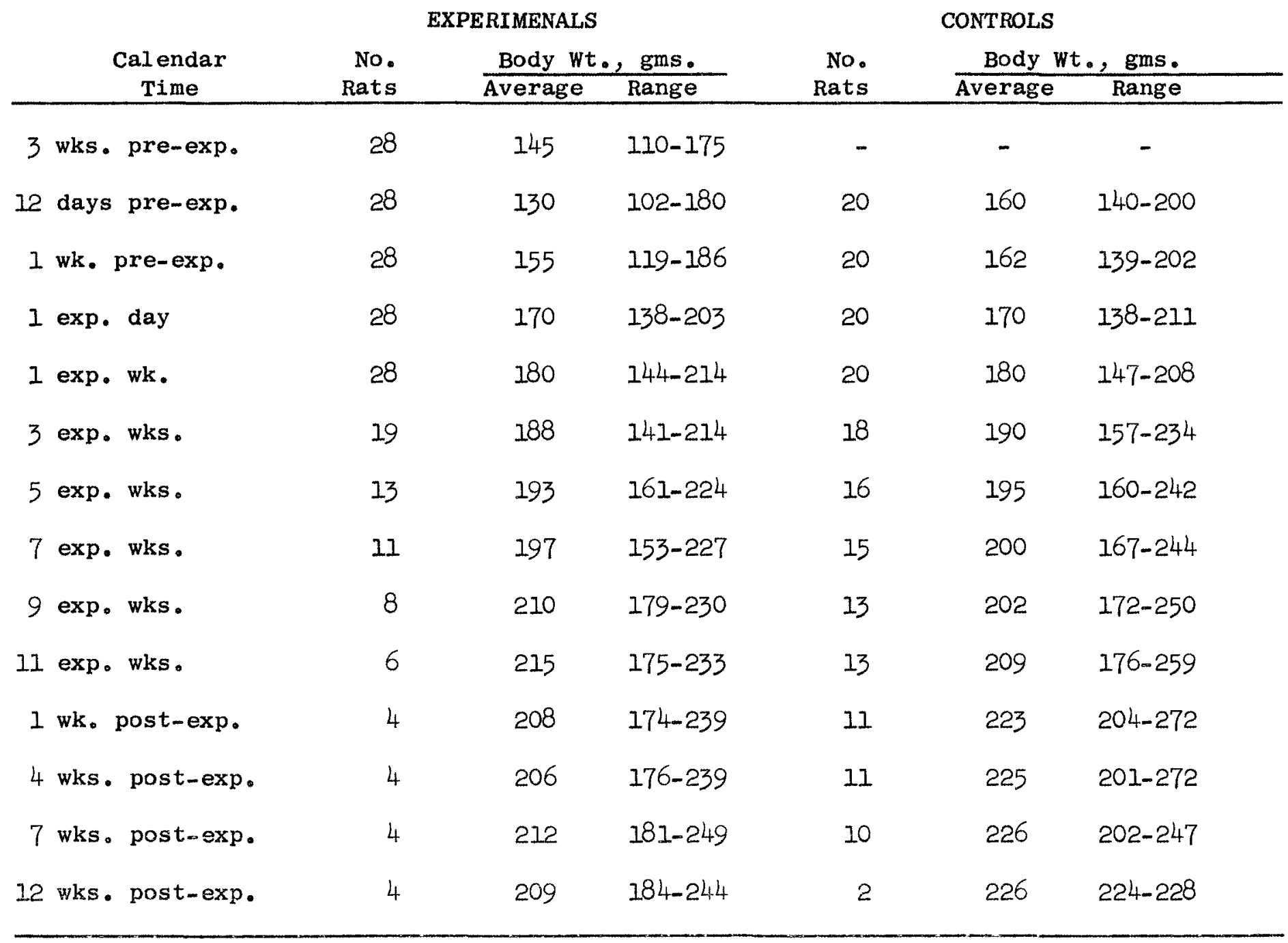




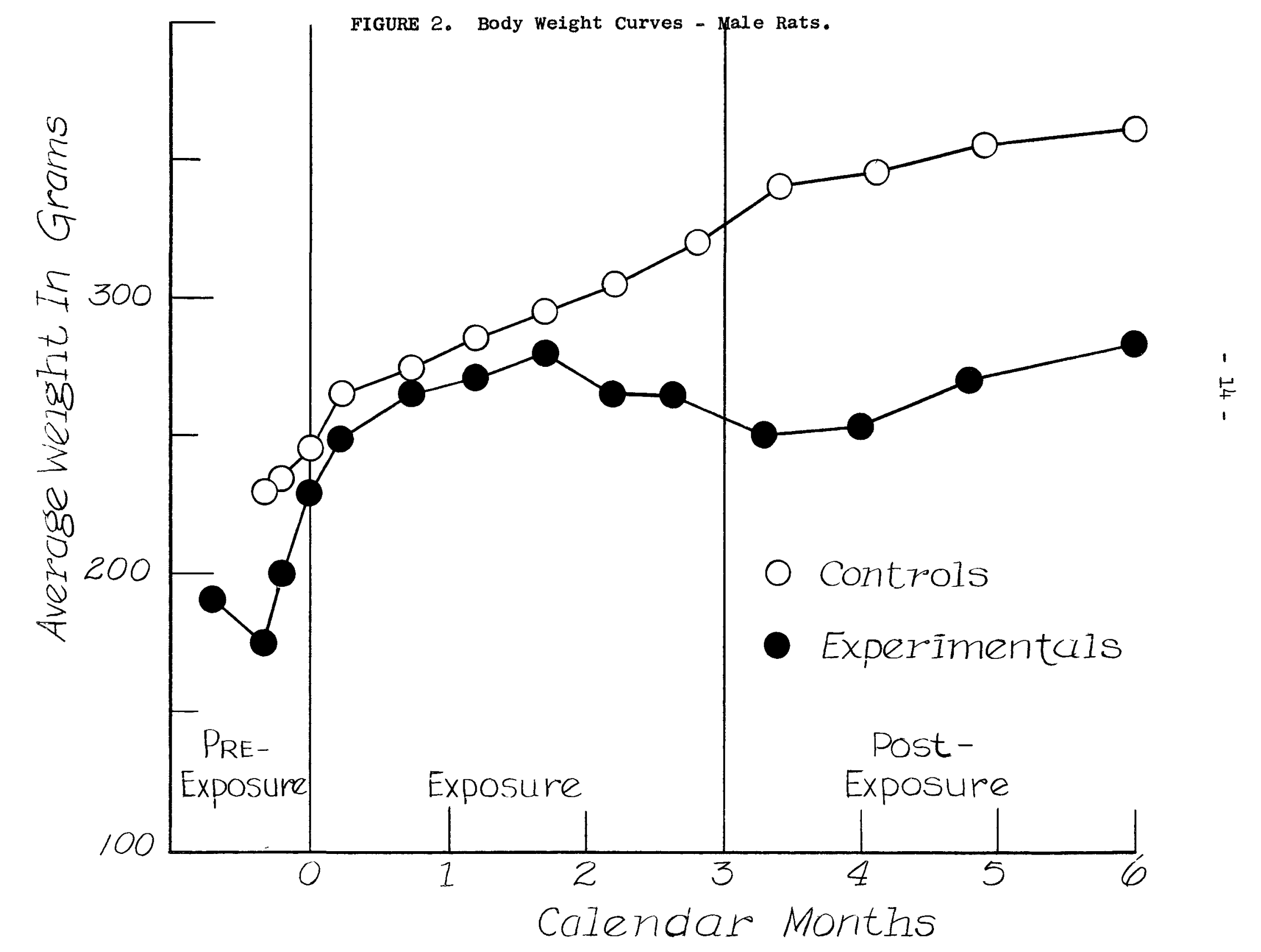


FIGURE 3. Body Weight Curves - Female Rats.

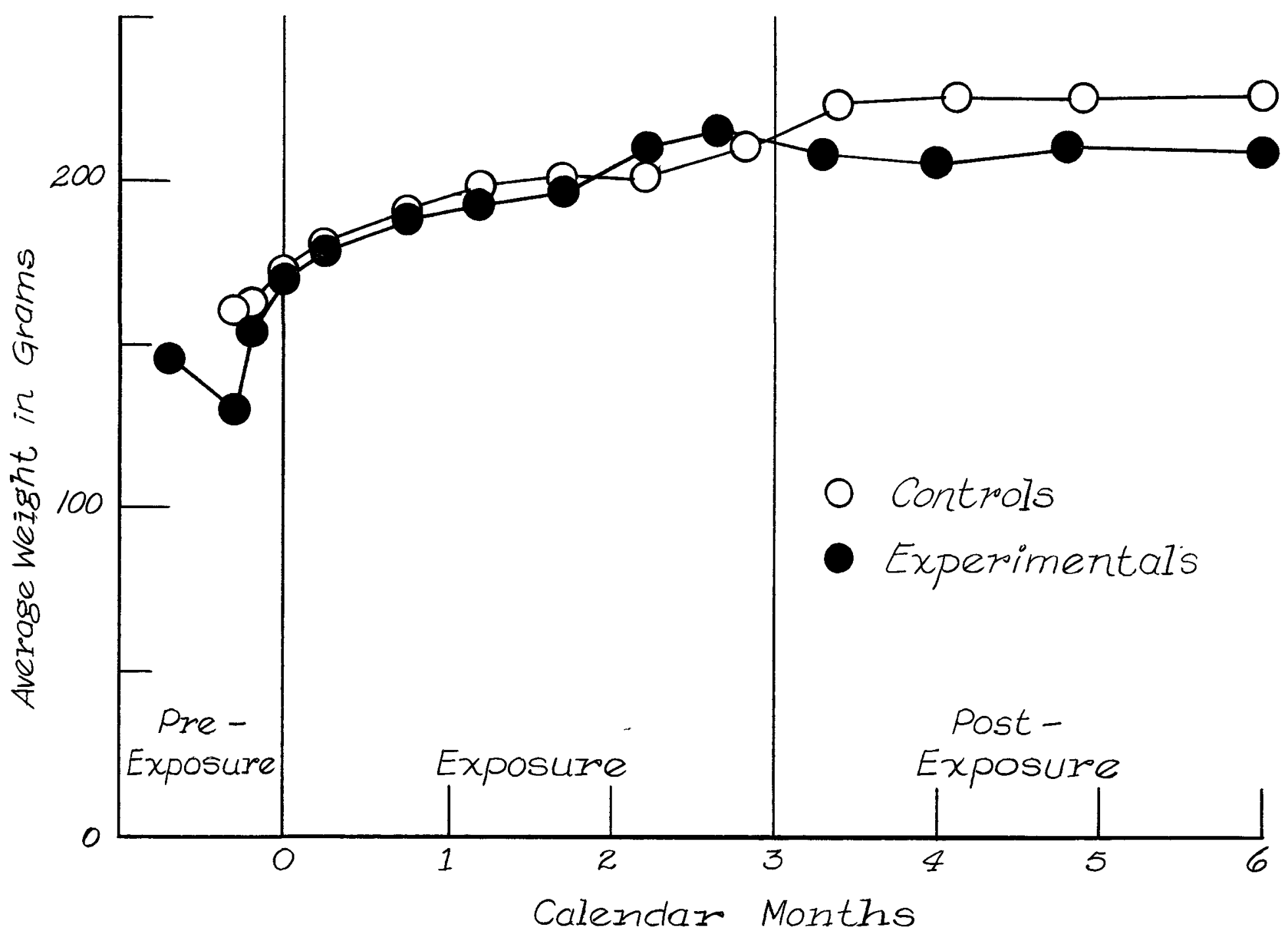


first post-exposure month when the body weights of the experimental males averaged 90 grams less than those of the controls. The slight recovery in growth during the latter part of the post-exposure period is of questionable significance because of the few (two) surviving animals. No adverse effects on the growth of the experimental female rats were observed.

\section{Hematology.}

Blood samples were taken from the rats pre-experimentally and at time of sacrifice. The average hematological values are presented in Table IV. The only evidence in these data of any effect on the blood picture from the inhalation of $\mathrm{In}_{2} \mathrm{O}_{3}$ was a 2 - to 3 -fold increase in the absolute neutrophil count. The average absolute neutrophil count for the experimental males and females was 4,592 and 6,483, respectively, during the pre-exposure period. After two weeks of exposure to $\mathrm{In}_{2} \mathrm{O}_{3}$ these values increased to 11,741 and 13,048 , respectively. This alteration in the differential white cell count continued throughout the post-exposure period; at 12 weeks post-exposure the average values were as follows: 13,414 for male rats, 13,308 for female rats. Lung Weights and Lung Weight-Body Weight Ratios.

At sacrifice the weights of the lungs of the experimental and control rats were recorded and the organ weight-body weight ratios calculated. This information is tabulated in Tables $V$ and VI. The lungs of the experimental males (Table V) and females (Table VI) were from three to five times heavier than those of the controls. These findings were reflected in the lung-weight-body weight ratios which for the experimental animals were approximately five times greater than the controls. 
TABLE IV

AVERAGE HEMATOLOGICAL VALUES

\begin{tabular}{|c|c|c|c|c|c|c|c|c|c|}
\hline Time & $\begin{array}{r}\text { No. } \\
\text { Rats }\end{array}$ & $\begin{array}{r}\text { Body } \\
\text { Weight } \\
\text { (gms) } \\
\end{array}$ & $\begin{array}{c}\mathrm{Hgb} . \\
\mathrm{gm} / 100 \mathrm{cc} .\end{array}$ & $\begin{array}{l}\text { Hemato- } \\
\text { crit \% }\end{array}$ & $\begin{array}{c}\text { Retic. } \\
\% \\
\end{array}$ & $\begin{array}{l}\text { Platelets } \\
\times \quad 100,000 \\
\end{array}$ & WBC & $\begin{array}{c}\text { Absolute } \\
\text { Neutrophil } \\
\text { Count }\end{array}$ & $\begin{array}{l}\text { Absolute } \\
\text { Lymphocyte } \\
\text { Count }\end{array}$ \\
\hline \multicolumn{10}{|c|}{ MALE RATS } \\
\hline 3 wks, pre-exp. & 10 & 178 & 15.9 & 55.8 & 3.4 & 6.7 & 20,375 & 4,592 & 14,759 \\
\hline 2 wks. exp. & 2 & 262 & 15.8 & 55.3 & 4.5 & 8.9 & 30,650 & 11,741 & 17,573 \\
\hline 4 wks. exp. & 2 & 273 & 17.8 & 64.5 & 2.6 & 10.5 & 27,150 & 8,990 & 17,404 \\
\hline 7 wks. exp. & 2 & 335 & 16.3 & 56.5 & 4.9 & 10.1 & 30,435 & 14,392 & 15,211 \\
\hline 12 wks. exp. & 2 & 311 & 16.3 & 58.8 & 3.3 & 8.4 & 36,400 & 15,653 & 15,649 \\
\hline 12 wlss. post-exp. & 2 & 284 & 15.5 & 54.3 & 4.0 & 8.1 & 27,825 & 13,414 & 13,299 \\
\hline
\end{tabular}

\section{FEMALE RATS}

\begin{tabular}{llllllllll}
3 wks. pre-exp. & 12 & 140 & 15.8 & 55.4 & 3.3 & 6.2 & 25,013 & 6,483 & 17,635 \\
2 wks. exp. & 2 & 197 & 12.8 & 46.0 & 9.6 & 8.3 & 24,725 & 13,048 & 10,853 \\
4 wks. exp. & 2 & 199 & 14.6 & 51.0 & 6.3 & 12.8 & 40,125 & 15,649 & 23,051 \\
7 wks. exp. & 2 & 186 & 14.0 & 49.5 & 6.6 & 9.8 & 30,300 & 14,676 & 14,392 \\
12 wks. exp. & 2 & 218 & 15.0 & 51.3 & 5.5 & 8.2 & 32,575 & 12,724 & 16,064 \\
12 wks. post-exp. & 4 & 209 & 15.4 & 52.8 & 4.5 & 7.8 & 30,625 & 13,308 & 12,783 \\
\hline
\end{tabular}


TABLE V

LUNG WEIGHTS AND LUNG WEIGHT-BODY WEIGHT RATIOS

Male Rats

\begin{tabular}{|c|c|c|c|c|c|c|c|}
\hline Time & $\begin{array}{r}\text { No. } \\
\text { Rats } \\
\end{array}$ & $\frac{\text { Body }}{\text { Average }}$ & $\frac{\text { Wt., gms. }}{\text { Range }}$ & $\begin{array}{r}\text { Lung } \\
\text { Average }\end{array}$ & $\frac{\text { Wt., gms. }}{\text { Range }}$ & $\frac{\frac{\text { Lung } w t,-B o d y}{\text { Average }}}{\text { A }}$ & $\frac{\mathrm{y} \text { W } \text { Ratio }}{\text { Range }}$ \\
\hline \multicolumn{8}{|c|}{ CONTROLS } \\
\hline 7 wks. exp. & 2 & 320 & $280-359$ & 1.39 & $0.96-1.81$ & 4.24 & $3.43-5.04$ \\
\hline 12 wks. exp. & 2 & 322 & $300-344$ & 1.26 & $1.19-1.33$ & 3.71 & $3.44-3.97$ \\
\hline 12 wks. post-exp. & 2 & 362 & $316-408$ & 1.65 & $1.52-1.78$ & 4.59 & $4.36-4.81$ \\
\hline \multicolumn{8}{|c|}{ EXPERIMENTALS } \\
\hline 7 wks. exp. & 2 & 335 & $320-345$ & 5.99 & $5.17-6.80$ & 17.8 & $16.1-19.4$ \\
\hline 12 wks. exp. & 2 & 311 & $274-347$ & 5.92 & $5.47-6.36$ & 19.5 & $15.8-23.2$ \\
\hline 12 wks. post-exp. & 2 & 284 & $284-284$ & 6.41 & $6.28-6.54$ & 22.6 & $22.1-23.0$ \\
\hline
\end{tabular}

* mg lung/gm body weight. 
TABLE VI

LUNG WEIGHTS AND LUNG WEIGHT-BODY WEIGHT RATIOS

Female Rats

\begin{tabular}{|c|c|c|c|c|c|c|c|}
\hline Time & $\begin{array}{r}\text { No. } \\
\text { Rats }\end{array}$ & $\frac{\text { Body }}{\text { Average }}$ & $\frac{\text { Wt. , gms. }}{\text { Range }}$ & $\frac{\text { Lung W }}{\text { Average }}$ & $\begin{array}{l}\text { gms. } \\
\text { Range }\end{array}$ & $\frac{\text { Lung wt.-Bod }}{\text { Average }}$ & $\frac{\mathrm{y} \text { Wt. Ratio* }}{\text { Range }}$ \\
\hline \multicolumn{8}{|c|}{ CONTROLS } \\
\hline 7 wks. exp. & 2 & 218 & $217-218$ & 1.13 & $1.05-1.20$ & 5.16 & $4 \cdot 79-5.53$ \\
\hline 12 wks. exp. & 2 & 191 & $176-205$ & 1.11 & $0.91-1.31$ & $5 \cdot 78$ & $5.17-6.39$ \\
\hline 12 wks. post-exp. & 2 & 226 & $224-228$ & 1.06 & $1.02-1.10$ & 4.69 & $4.47-4.91$ \\
\hline \multicolumn{8}{|c|}{ EXPERIMENTALS } \\
\hline 7 wks. $\exp$ & 2 & 186 & $178-194$ & 3.44 & $3.15-3.72$ & 18.4 & $17.7-19.1$ \\
\hline 12 wks. exp. & 2 & 218 & $208-228$ & 5.53 & $5 \cdot 31-5 \cdot 75$ & 25.5 & $23.3-27.6$ \\
\hline 12 wks. post-exp. & 4 & 209 & $184-284$ & 4.43 & $3.76-4.98$ & 21.3 & $19.2-23.4$ \\
\hline
\end{tabular}

* mg lung/gm body weight. 
Indium Content of Tissues.

portions of selected tissues from rats sacrificed at various intervals during the experiment were analyzed spectrographically for indium. Average indium concentrations and ranges, expressed in micrograms of indium per gram of fresh tissue $(\mu \mathrm{g} / \mathrm{g})$ are given in Table vII. As seen in this table, the lungs and PLN contained by far the most indium. Average values for these tissues (1 ung and PLN) increased from 490 and $250 \mu \mathrm{g} / \mathrm{g}$, respectively, after two weeks of exposure to 1000 and $1300 \mathrm{\mu g} / \mathrm{g}$ after 12 weeks. Postanposure data (1 ung: $420 \mu \mathrm{g} / \mathrm{g}$, PLN: $410 \mu \mathrm{g} / \mathrm{g}$ ) indicate that approximately 58 per cent of the indium had been mobilized from the lung and 69 per cent from the PLN, 12 weeks after termination of exposure.

For other tissues, i॰e., liver, kidney, and spleen the indium content was low. After two weeks of exposure average values were as follows: liver, $0.33 \mu \mathrm{g} / \mathrm{g}$; kidney, $1.8 \mathrm{\mu g} / \mathrm{g}$; and spleen, $0.25 \mu \mathrm{g} / \mathrm{g}$. Later in the experiment, viz., 12 weeks post-exposure, the indium content increased 40-fold in the liver, 6-fold in the kidney and 80-fold in the spleen.

In the bone, deposition occurring between four weeks and the end of the post-exposure period represented a 20 -fold increase in the indium content.

In Figure 4 indium concentrations in the tissues are plotted on a $\log$ scale against time on a linear abscissa. From the lung and PLN curves (Figure 4) one can estimate the biological half-time for indium to be $21 / 2$ months in the lung and $13 / 4$ months in the PLN. These estimations 
TABLE VII

INDIUM CONTENT OF TISSUES OF RATS EXPOSED TO $\mathrm{In}_{2} \mathrm{O}_{3}$ DUST

Values in Micrograms of In per Gram Fresh Tissue

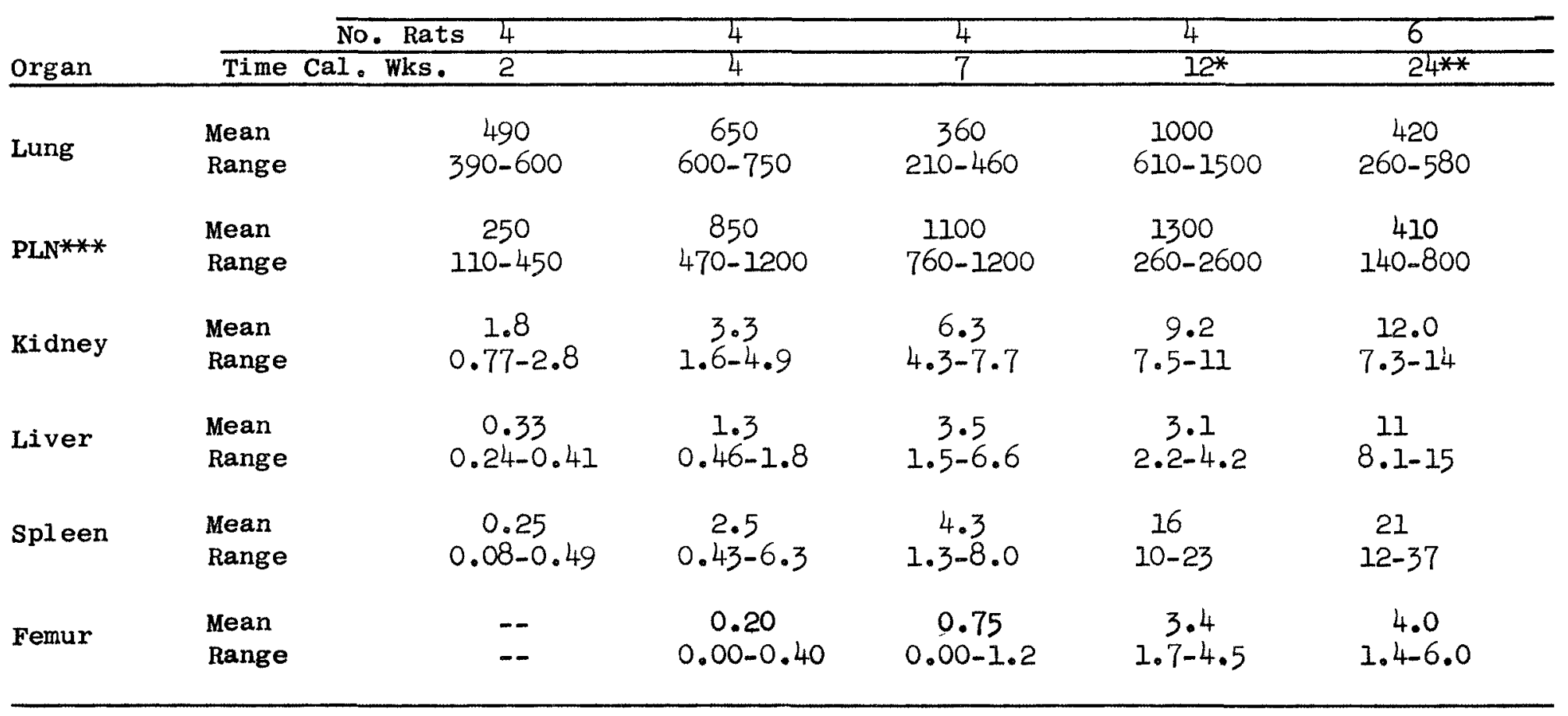

* Termination of exposure

** 12 weeks post-exposure

*** tracheobronchial $1 \mathrm{ymph}$ nodes 
indicate that $\mathrm{In}_{2} \mathrm{O}_{3}$ is mobilized from the lung and PLN at a much faster rate than are the "insoluble" oxides of beryllium, thorium, or uranium. It is interesting to note that mobilization of indium from the Iungs and PLN during the post-exposure period is reflected, at least in part, by the increased indium content of the kidney, liver, bone and spleen. The tissues of control rats were essentially free of indium.

Pathology.

The only gross findings seeming to result from inhaling $\mathrm{In}_{2} \mathrm{O}_{3}$ dust were increase in lung weight, increase in consistency of the lungs and enlargement of the tracheobronchial lymph nodes.

Microscopic Findings: Lesions observed that could be attributed to the inhalation of $\mathrm{In}_{2} \mathrm{O}_{3}$ were limited to the lungs and tracheobronchial 1 ymph nodes. In all of the lungs examined at the various time periods there was present in the alveoli a peculiar eosinophilic, granular, probably protein-containing, fluid (Figures 5, 6 and 7). There was wide distribution of the fluid throughout the lung; however, areas of air. containing alveoli, sometimes emphysematous, were present。 The fluid was also seen in some of the terminal bronchi. A few cells, viz。, alveolar phagocytes and polymorphonuclears, were always present in the fluid in addition to some nuclear debris. In some lungs small foci of consolidation, made up mostly of polymorphonuclears, were observed (Figure 8 ). The alveolar phagocytes, with both vacuolated and non-vacuolated cytoplasm, were present either resting on the alveolar wall or free in the fluid (Figures 6 and 7). Frequently edema about the large vessels was seen. The alveolar walls were rather markedly altered. Many foci were observed in which the alveolar wall appeared to consist of an avascular 


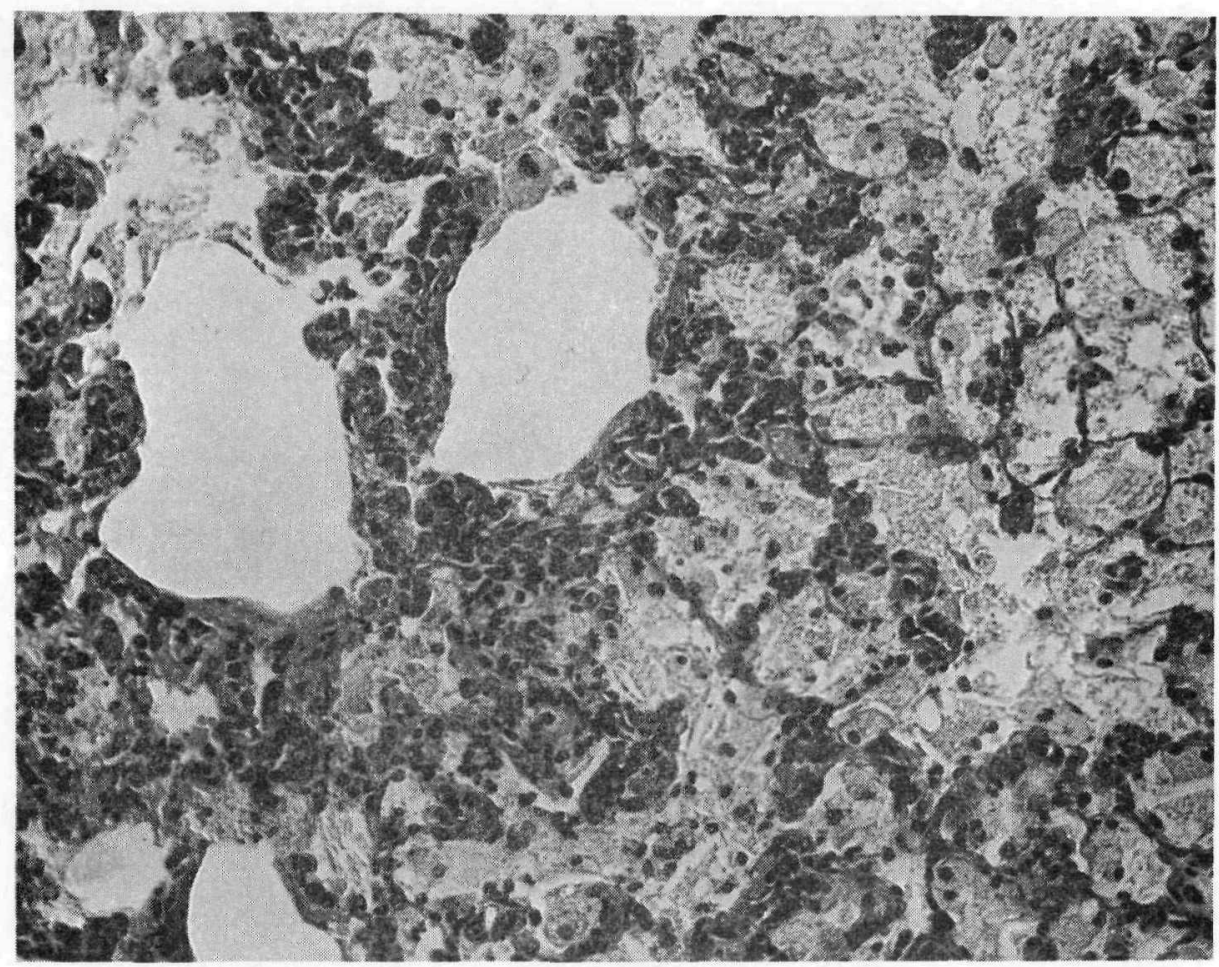

FIGURE 5. Lung ( $H$ and $E$ Mag. $x 150$ ) 12 weeks post-exposure.

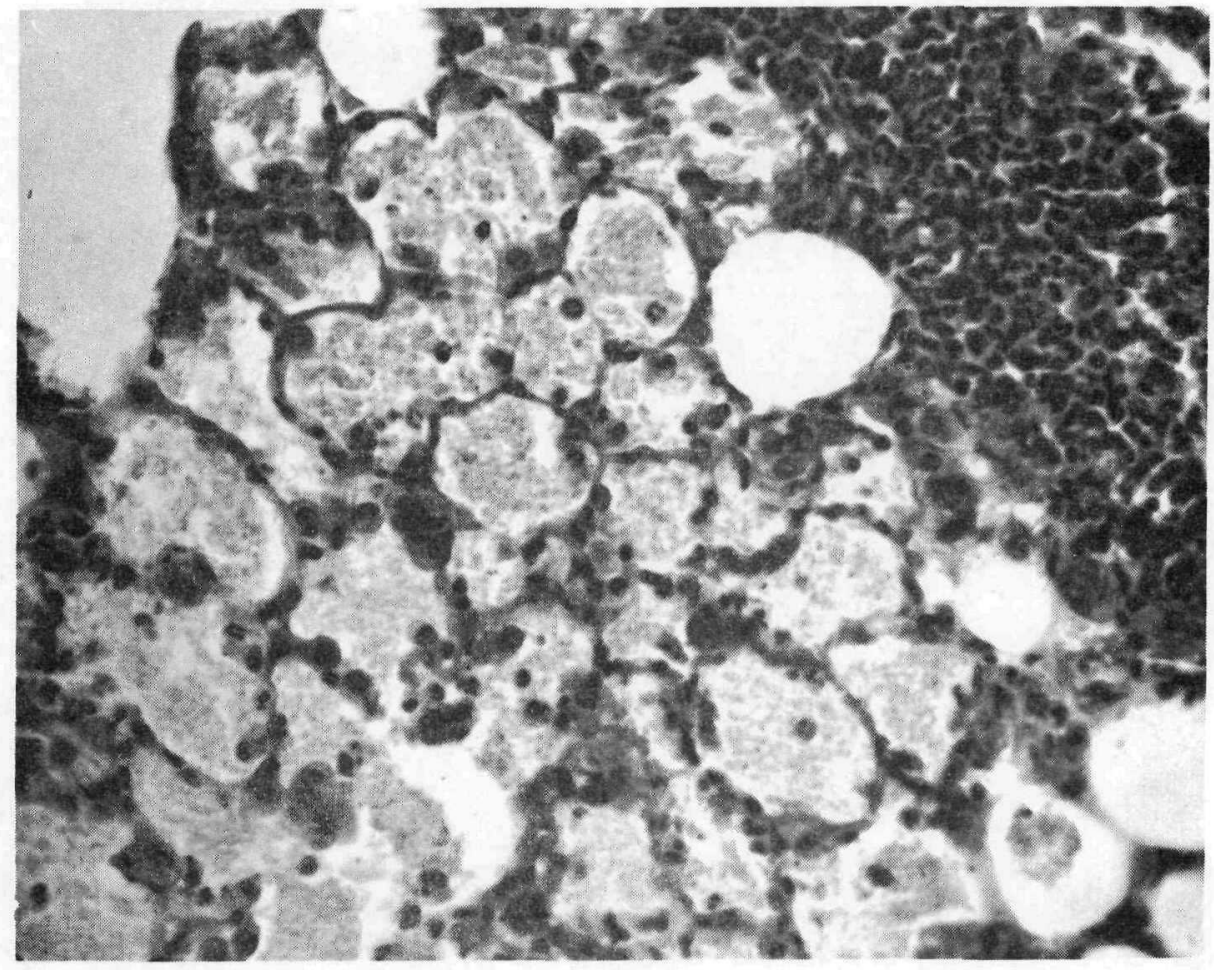

FIGURE 6. Lung ( $\mathrm{H}$ and $\mathrm{E}$ Mag. $\mathbf{x} 300$ ) 2 weeks exposure. 


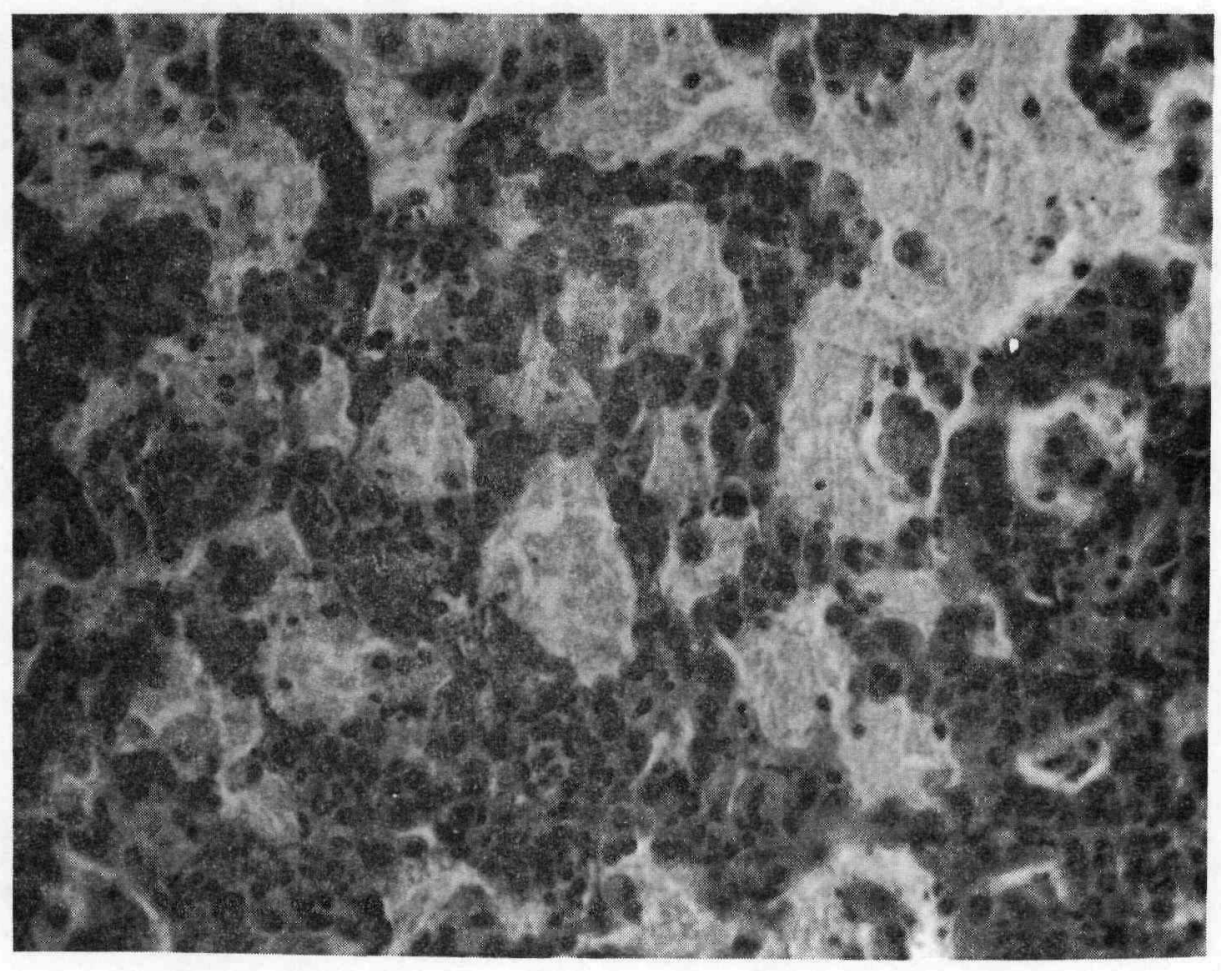

FIGURE 7. Lung ( $\mathrm{H}$ and $\mathrm{E}$ Mag. $\mathrm{x}$ 300) 7 weeks exposure.

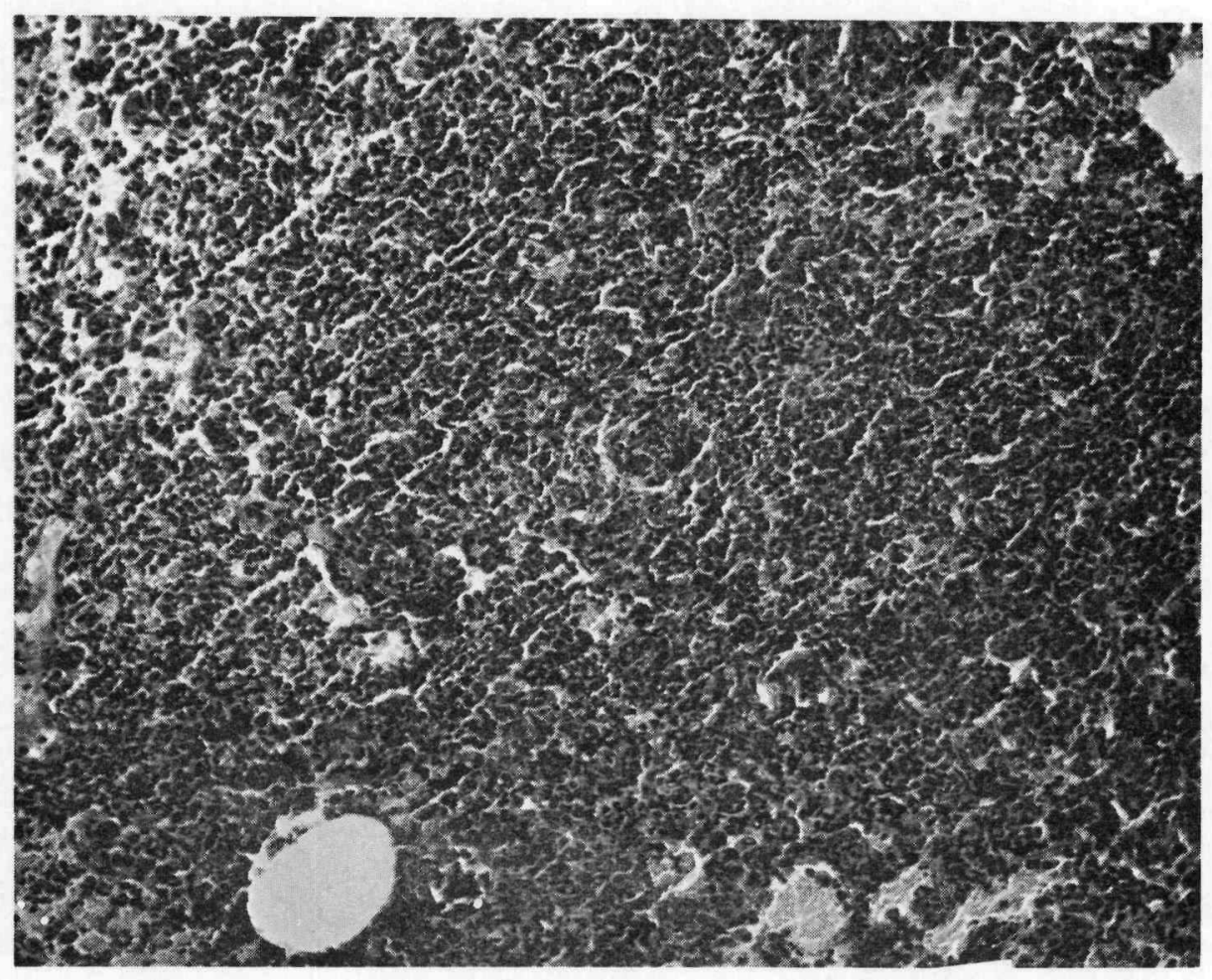

FIGURE 8. Lung ( $\mathrm{H}$ and $\mathrm{E}$ Mag. x150) 7 weeks exposure. 
strand of spindle-shaped elongated cells made up mostly of cytoplasm and a few nuclei (Figures 5 and 6). Large round cells, probably either alveolar phagocytes or alveolar epithelial cells, were seen resting on this membrane. In other areas the alveolar walls were lined by large, ovoid or cuboidal cells presumably alveolar epithelium (Figure 7). The character of the lesions remained, in general, much the same regardless of the period of exposure. In the lungs of the animals sacrificed 12 weeks after cessation of exposure the extent of edema and exudation was somewhat less than that seen previously (Figure 5)。

A yellowish staining particulate material could be seen in the lungs and tracheobronchial lymph nodes after seven weeks exposure; this became more prominent in the nodes as time went on and was greatest in animals sacrificed 12 weeks post-exposure (Figure 9). The lymph nodes from all exposed animals were enlarged, and this enlargement seemed to be a result of hyperplasia of the lymphoid elements; however, the germinal centers were about normal in size.

Fourteen of the experimental animals exhibited acute purulent pleurisy and pericarditis. The kidneys of two animals showed mild interstitial nephritis. Focal necrosis of the liver was observed in two animals.

\section{DISCUSSION}

The results of this study clearly indicate that $\mathrm{In}_{2} \mathrm{O}_{3}$, when inhaled at relatively high concentrations $\left(64 \mathrm{mg} / \mathrm{m}^{3}\right)$ can produce toxic manifestations in rats. Evidence of chemical toxicity was found in body weight 


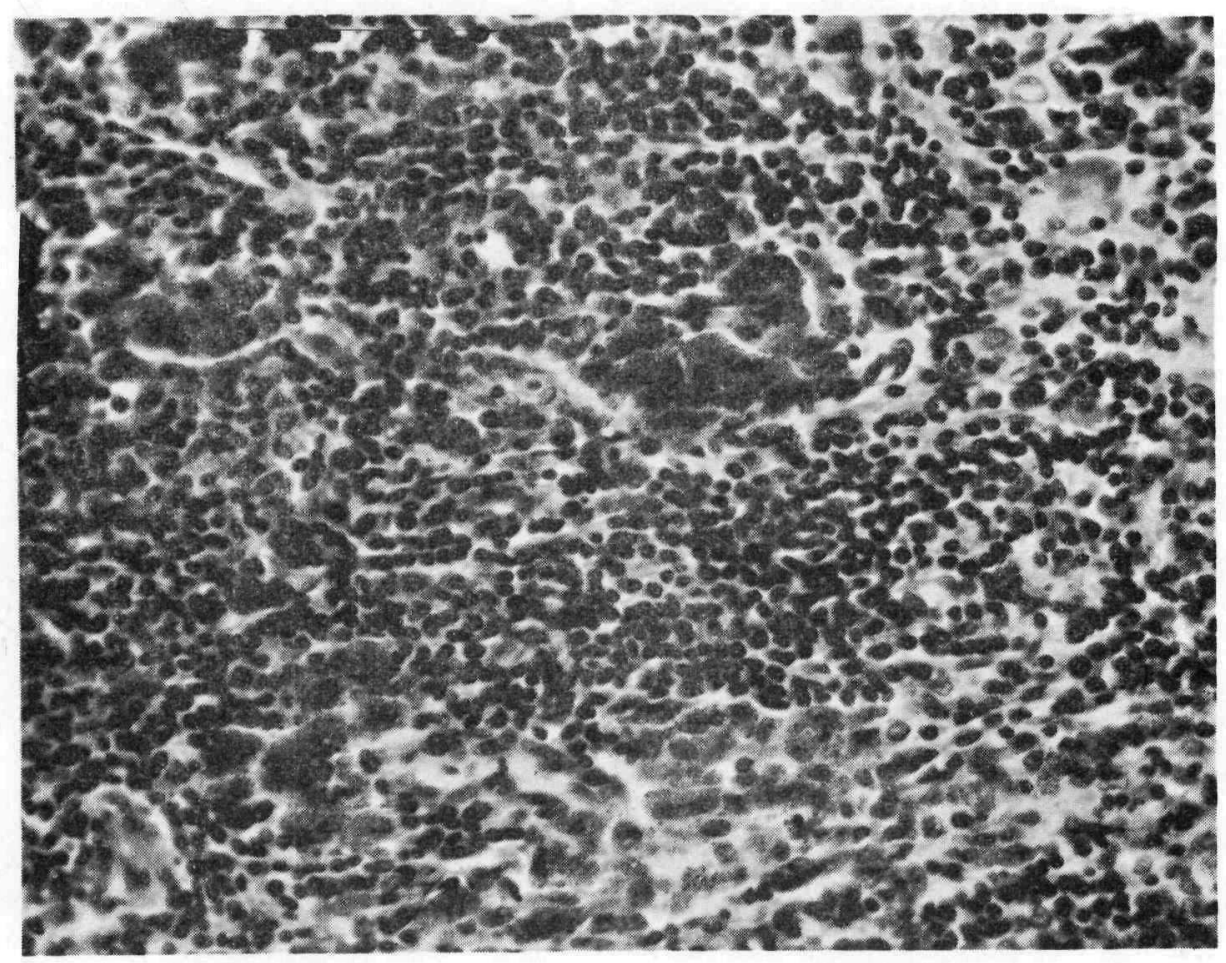

FIGURE 9. Tracheobronchial Lymph Node ( $\mathrm{H}$ and $\mathrm{E}$ Mag. $\mathrm{x} 300$ ) 12 weeks post-exposure. 
changes in male rats, in the hematological picture, and in the gross and histological condition of the lungs and tracheobronchial lymph nodes. Mortality during the 3-month exposure period, was approximately six times greater in the indium-exposed animals than in the control group. It is difficult to say with any degree of certainty that the mortality figures directly reflect the toxicity of indium because various intercurrent infections were the usual causes of death in the experimental group. Whether the exposure to indium increased the incidence or severity of these diseases is an unanswered question. Further work should be done to resolve this important point.

Another important physiological property of indium is its mobility. In this experiment, inhaled $\mathrm{In}_{2} \mathrm{O}_{3}$ was mobilized from the primary site of deposition, the lung at a faster rate and possibly in a different manner, than are the "insoluble" oxides of beryllium, thorium, or uranium. This is borne out by the relatively short biological halftime of $2 \mathrm{I} / 2$ months for $\mathrm{In}_{2} \mathrm{O}_{3}$ in the lungs of rats, as compared to estimations of 6 to 8 months for $\mathrm{BeO}, \mathrm{ThO}_{2}$, and $\mathrm{NO}_{2}$. This difference might be related to the increased solubility of $\mathrm{In}_{2} \mathrm{O}_{3}$ in body fluids, and/or the smaller particle size of the airborne indium trioxide dust. The most striking evidence of the physiological activity of $\operatorname{In}_{2} \mathrm{O}_{3}$ was the changes observed in the lungs of the indium-exposad animals. These lungs were three to five times heavier than those of the controls. Upon microscopic examination, lesions were observed that were probably inflammatory in character. However, they differed from the usual inflammatory reaction in the relative paucity of inflammatory cellular exudate. It is somewhat odd (1) that the lesions changed little over 
the periods of exposure and post-exposure and (2) that there was no fibrosis resulting from the healing process. In a few of the lungs from the 3-month post-exposure group a few small foci of early fibrosis were seen; however, it is difficult to attribute this with certainty to the treatment received.

\section{SUMMARY}

1. Indium sesquioxide $\left(\operatorname{In}_{2} \mathrm{O}_{3}\right)$ is moderately toxic when inhaled by rats.

2. In a 3-month dust exposure, at a level of $64 \mathrm{mg} \mathrm{In}_{2} \mathrm{O}_{3} / \mathrm{m}^{3}$, signs of chemical toxicity included growth depression in male rats, abnormalities in hematological values, and changes in the gross and histological condition of the lungs and tracheobronchial 1 ymph nodes.

3. Retention of indium following inhalation of $\mathrm{In}_{2} \mathrm{O}_{3}$ dust was primarily in the lungs and tracheobronchial 1ymph nodes. These tissues averaged 1000 and $1300 \mu \mathrm{g} / \mathrm{n} / \mathrm{g}$ fresh tissue, respectively, after three months of exposure. Only a small fraction of the inhaled Indium appeared in the other tissues examined; the spleen was highest with an average value of $16 \mu \mathrm{g} / \mathrm{g}$, followed, in order, by the kidney $(9 \mu \mathrm{g} / \mathrm{g})$, the bone $(3 \mu \mathrm{g} / \mathrm{g})$ and the Iiver $(3 \mu \mathrm{g} / \mathrm{g})$.

4. Indium is mobilized from the site of entry into the body, and distributed to other tissues and probably excreted in urine and feces. For example, three months following exposure the distribution of indium in the body was as follows: lungs, 420; tracheobronchial lymph nodes, 410; spleen, 2l; kidney, 12; Iiver, 11 and bone, $4 \mu \mathrm{g} \mathrm{In/g}$, respectively. 5. Under the conditions of this experiment the biological halftime for $\mathrm{In}_{2} \mathrm{O}_{3}$ in the lungs of rats was estimated to be about $21 / 2$ months. 


\section{REFERENCES}

1. Downs, W. L., et al。: The toxicity of indium. University of Rochester Atomic Energy Project Report, UR-558 (1959).

2. Smith, G. A., et al.: The metabolism of indium ${ }^{14 M}$ administered to the rat by intratracheal intubation. University of Rochester Atomic Energy Project Report, UR=500 (1957)。

3. Smith, G. A. et al。: The metabolism of indium. II. The distribution and excretion of subcutaneous injection. University of Rochester Atomic Energy project Report, UR-507 (1957)。

4. Morrow, P. E。, et al。: Fate of indium sesquioxide and of indium ${ }^{214}$ trichloride hydrolysate following inhalation in rats. University of Rochester Atomic Energy Project Report, UR-508 (1958).

5. Wright, B. M०: A new dust feed mechanism. J. Sci. Inst. 27, $12(1950)$. 